\title{
The neuroendocrine timing of puberty
}

\author{
Francis J P Ebling \\ School of Biomedical Sciences and Institute of Neuroscience, University of Nottingham Medical School, Queen's \\ Medical Centre, Nottingham, NG7 2UH, UK
}

Correspondence should be addressed to F Ebling; Email: fran.ebling@nottingham.ac.uk

\begin{abstract}
Puberty is the attainment of fertility, a process encompassing morphological, physiological and behavioural development. The increased hypothalamic secretion of the gonadotrophin-releasing hormone decapeptide $(\mathrm{GnRH})$ is essential for the activation of the pituitary-gonadal axis at puberty. The GnRH secretory network initially develops and is temporarily active during species-specific periods of fetal/neonatal development, so puberty is the secondary reactivation of an existing system. From a neurobiological perspective, the timing of puberty is therefore a function of changes in the neural systems controlling $\mathrm{GnRH}$ release. The large variability between individuals in the onset and progression of puberty indicates that the timing of puberty is not simply a function of chronological age. Rather, the neurotransmitter and neuromodulatory systems that impact upon the GnRH secretory network convey information about metabolic fuels, energy stores and somatic development and, for many species, information about season and social environment. The clear links demonstrated between metabolic fuel availability and reproductive function in many animal models provides evidence that the earlier onset of pubertal development observed in girls in certain US study populations is likely to relate to the increasing prevalence of overweight and obesity in adolescents.

Reproduction (2005) 129 675-683
\end{abstract}

\section{Gonadotrophin-releasing hormone (GnRH-I) secretion is essential for puberty}

In neuroendocrine terms, puberty is the reactivation of gonadotrophin-releasing hormone $(\mathrm{GnRH})$ secretion (Fig. 1). Gene duplication has led to multiple forms of this hormone being produced in vertebrates (Fernald \& White 1999), but the profound infertility observed in the hypogonadal (hpg) mouse in which the GnRH-I gene is mutated such that it is not translationally competent, elegantly demonstrates the critical importance of this particular gene product in mammals (Cattanach et al. 1977, Charlton 2004). It was first demonstrated over two decades ago that treatment of prepubertal primates with appropriate pulsatile patterns of GnRH alone induces puberty (Wildt et al. 1980). The necessary and sufficient role of GnRH-I (henceforth referred to as $\mathrm{GnRH}$ ) in causing puberty in mammals has been further demonstrated by the lack of gonadotrophin synthesis and secretion, and the retardation of reproductive development or the loss of reproductive function in adulthood when the action of $\mathrm{GnRH}$ has been blocked by immunoneutralisation, treatment with $\mathrm{GnRH}$ antagonists, or by treatment with agonists which paradoxically down-regulate the secretory activity of gonadotrophs in the pituitary gland. Conversely, treatment of infertile $h p g$ mice with synthetic $\mathrm{GnRH}$ or with grafts of wild-type fetal hypothalamic tissue containing normal GnRH neurons, or by gene therapy induces spermatogenesis in males (Mason et al. 1986). Such grafts also induce ovarian maturation in females such that ovulation can be induced by exposure to sexually active males and pregnancy established (Gibson et al. 1984), confirming the critical role of $\mathrm{GnRH}$ in reproductive maturation. Thus, the ultimate attainment of fertility, reflecting morphological, physiological and behavioural development, is a consequence of the increased synthesis and release of this decapeptide with unusual terminal modifications. It is perhaps surprising, given the absolute requirement for increased $\mathrm{GnRH}$ secretion to cause reproductive maturation, that this remarkable neuroendocrine output is produced by less than 2000 neurons in the mammalian brain (Ebling \& Cronin 2000).

\section{Development of the GnRH secretory system}

Another remarkable feature of this $\mathrm{GnRH}$ secretory system is that the key population of $\mathrm{GnRH}$ neurons originates in the embryonic period outside of the central nervous system in the medial olfactory placode (Tobet et al. 2001). These cells subsequently migrate from the nasal region into the brain, such that the neuronal cell soma which 


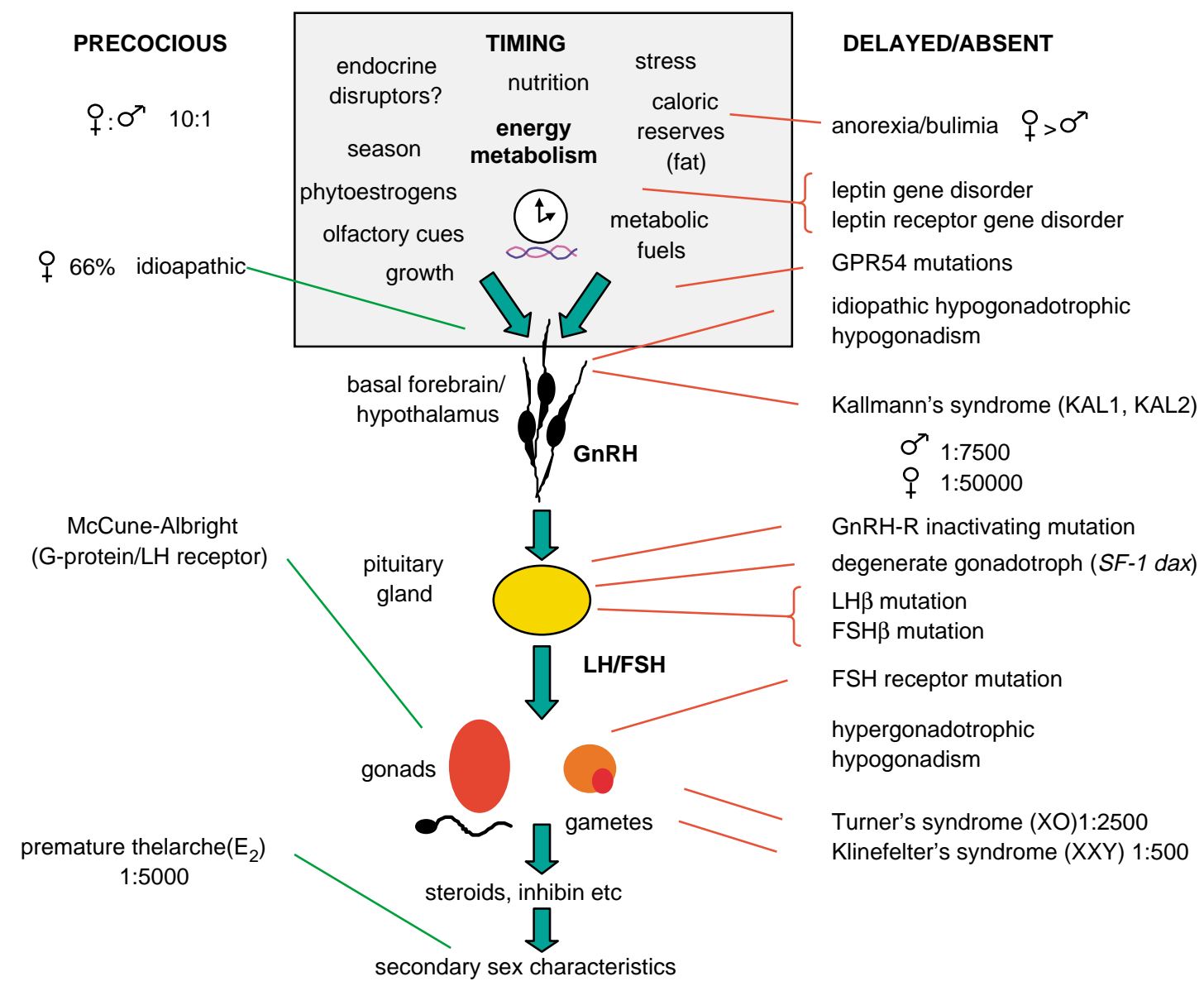

Figure 1 The timing of puberty is a function of the central control of GnRH secretion, reflecting the integration of multiple internal and external cues acting upon a genetically determined process. Some major disorders of the timing of puberty are indicated that reflect dysfunction at different levels of the hypothalamo-pituitary-gonadal axis. $\mathrm{E}_{2}$, oestradiol; $\mathrm{FSH}$, follicle-stimulating hormone; GnRH-R, gonadotrophin-releasing hormone receptor.

constitute the GnRH secretory system in the adult mammal are dispersed in a rostro-caudal continuum through the basal forebrain from the medial septum to the mediobasal hypothalamus. The majority of cell bodies are found in rostral areas, particularly the medial septum, diagonal band of Broca, and in the preoptic area (POA) at the level of the organum vasculosum of the lamina terminalis (OVLT). In primates and man, a proportion of the GnRHimmunoreactive perikarya are also located more caudally in the retrochiasmatic area, and in the mediobasal hypothalamus and arcuate nucleus (Song et al. 1987, Dudas \& Merchenthaler 2003). Retrograde tracing studies reveal that the great majority of $\mathrm{GnRH}$ neurons extend axonal projections to the capillary beds of the OVLT and median eminence (Witkin 1990), although extensive branching also results in innervation of midbrain sites where $\mathrm{GnRH}$ has been hypothesised to facilitate certain reproductive behaviours. Such observations lead to the view that the major role of $\mathrm{GnRH}$, at least in the postnatal period, is via secretion into the pituitary portal circulation ultimately to regulate pituitary gonadotroph function.
This recent understanding of the development of the GnRH secretory system provides an explanation for Kallmann's syndrome (Fig. 1), where the timing of puberty may be grossly delayed or absent resulting in complete infertility (MacColl et al. 2002). In the great majority of cases the hypogonadotrophic hypogonadism is linked with anosmia, the complete lack of a sense of smell, or hyposmia. This association between olfactory deficits and reproductive maturation was first described by Maestre de San Juan in 1856, who reported an autopsy of a 40-yearold man with a micropenis, very undersized cryptorchid testicles, and absent olfactory bulbs (Munoz \& Dieguez 1997). Kallmann (1944, cited in Quinton et al. 1996) later reported that this association occurred within families, establishing its genetic basis, although it can also occur as a sporadic disorder. The lack of $\mathrm{GnRH}$ secretion underlying the hypogonadotrophism is a consequence of incomplete migration of $\mathrm{GnRH}$ neurons from the olfactory placode to the brain, which, in turn, is linked to dysgenesis of the olfactory bulbs. The syndrome is far more prevalent in males than females, by a factor of $5: 1$. This 
results from a common form in which there is X-linked inheritance, and the underlying mutation is in the KAL-1 gene which encodes a protein with homology to the cell surface adhesion molecule N-CAM (MacColl et al. 2002). Presumably the failure of $\mathrm{GnRH}$ neurons to migrate appropriately in such individuals reflects the non-permissive nature of the neural substrate over which migration along the olfactory nerve takes place.

\section{Developmental changes in GnRH gene expression}

The observation that the neural substrate for puberty develops so far in advance of the onset of puberty raises the question of why the GnRH secretory system does not become active and drive puberty as soon as it has developed. The idea that GnRH gene expression is arrested, and thus the synthetic capacity of the GnRH secretory network is limiting, has been addressed using a variety of experimental approaches in several different species. However, there is little evidence that changes at the level of $\mathrm{GnRH}$ gene expression are limiting the timing of puberty. For example, in the male mouse, GnRH mRNA abundance as assessed by in situ hybridisation increases significantly between the day of birth and five days of age, but then remains high through to adulthood (Ford \& Ebling 2000), that is, there are no further increases at times when increases in gonadotrophin secretion and testosterone concentrations occur. Likewise, in a study of $\mathrm{C} 57 \mathrm{BI} / 6$ mice in which cytoplasmic GnRH mRNA and nuclear primary transcript levels were separately assessed by RNase protection assays, a gradual developmental trend in cytoplasmic GnRH mRNA was reported, but most of the increase occurred by postnatal day 20 in females, and before postnatal day 28 in males (Gore et al. 1999). Moreover, the major increase in levels of nuclear GnRH transcripts as determined by RNase protection assay occurred between postnatal day 0 and postnatal day 7 in both sexes (Gore et al. 1999). These findings in the mouse are complemented by many studies in the rat. In an in situ hybridisation study in the male rat, no increases in GnRH mRNA levels were detected at the time of the pubertal increase in plasma testosterone, that is, after 25 days of age (Wiemann et al. 1989). However, significant increases were observed at earlier ages, as determined by solution hybridisation RNAse protection assays (Gore et al. 1996) or by PCR-based assays of hypothalamic extracts (Dutlow et al. 1992). Differences in the choice of time points studied make it difficult to compare directly the various studies in rats and mice, but in general the major developmental increase in $\mathrm{GnRH}$ gene expression in the mouse occurs at a younger age than in the rat, consistent with the earlier increases in gonadotrophin secretion in mice.

In a more limited number of studies in primates comparing GnRH mRNA abundance or hypothalamic GnRH content between prepubertal and postpubertal stages, there is little evidence for changes in the capacity to synthesise or store GnRH (Fraser et al. 1989, Vician et al. 1991). Thus, the common finding across many mammalian studies is that increases in $\mathrm{GnRH}$ gene expression and translation precede the increases in gonadotrophin secretion which drive gonadal maturation (reviewed in Plant 2001). It seems highly unlikely that insufficient expression of the $\mathrm{GnRH}$ gene is limiting the timing of pubertal development. Moreover, any changes in mRNA abundance occurring at the time of puberty are more likely to reflect post translational mechanisms, for example increased stabilisation of the $\mathrm{mRNA}$, rather than changes in the primary transcription rate (Gore \& Roberts 1997).

\section{Puberty as a reactivation of GnRH secretion}

The studies briefly summarised above demonstrate that the anatomical development of the GnRH secretory system occurs relatively early in life, and that the synthetic capacity is present well before puberty in that $\mathrm{GnRH}$ mRNA expression reaches adult levels. In some species the GnRH secretory system is undoubtedly active in the mid-late fetal period or neonatal period. Studies in the fetal sheep reveal that luteinising hormone $(\mathrm{LH})$ is released in a pulsatile manner during mid-late pregnancy, and the frequency of pulses increases if the fetal testis is removed (Mesiano et al. 1991). It is highly likely that the episodic release of $\mathrm{LH}$ reflects pulsatile release of $\mathrm{GnRH}$ from the fetal hypothalamus; indeed pharmacological blockade of $\mathrm{GnRH}$ action in fetal lambs results in a substantial reduction in testicular volume in later life (Brooks et al. 1995), evidence that activation of $\mathrm{GnRH}$ secretion early in life is important in testicular development. In male primates including humans there are periods of activation both in the fetal period and in the very early neonatal period (Plant 1985, Mann \& Fraser 1996). These early periods of activation of the GnRH secretory system may be important for masculinisation of the brain, development of subsequent sexual behaviour, and control of Sertoli cell proliferation in the testis. In female primates, it seems that a low level of activity of the GnRH secretory system is present throughout the juvenile period (Pohl et al. 1995). Birth is an arbitrary event in the development of an organism, so the periods of activation of $\mathrm{GnRH}$ secretion occurring prenatally in precocious species such as the sheep may be equivalent to the postnatal periods of activation in altricial species such as the mouse. In general, the rapidity of growth and development in mammals with a short life span, for example laboratory strains of rats and mice, is such that the initial fetal/neonatal period of activation is continuous with and indistinguishable from the subsequent pubertal activation of the hypothalamo-pituitary-gonadal axis, so there is no juvenile hiatus as in larger mammals with longer life spans. However, some small mammals can display periods of juvenile reproductive quiescence, particularly when the reactivation of $\mathrm{GnRH}$ secretion is timed by 
environmental cues such as changing photoperiod. For example, Siberian hamsters will rapidly grow and initiate puberty when raised in long photoperiods, but maintain a juvenile hiatus in development when exposed to short photoperiods signalling the onset of winter (Ebling 1994, Ebling \& Cronin 1998).

Since the synthetic capacity of $\mathrm{GnRH}$ neurons is not limiting for puberty to proceed, and a period of endogenous $\mathrm{GnRH}$ secretion has already occurred earlier in development, puberty can be viewed as a reactivation of $\mathrm{GnRH}$ secretion. A great deal of attention has been paid to the issue of whether the GnRH secretory system is actively inhibited during the prepubertal period or is simply dormant, waiting to acquire stimulatory inputs. The concept of the 'gonadostat' has arisen; this suggests that the low levels of androgen/oestrogen released by the prepubertal testes and ovaries exert negative feedback effects that inhibit $\mathrm{GnRH}$ release prior to puberty. Whilst there is no doubt that such homeostatic feedback mechanisms play an essential role in the regulation of the reproductive axis, it is clear that the decrease in GnRH secretion in the neonatal primate, and the primary activation of $\mathrm{GnRH}$ secretion in the juvenile period are processes that are independent of gonadal steroid feedback. This is elegantly demonstrated by the decrease in gonadotrophin secretion after the neonatal period and the subsequent increase in the juvenile period in rhesus monkeys that have been castrated at birth to remove any confounding influence of gonadal steroid feedback (Plant 1985). However, the juvenile increase in gonadotrophin secretion in such agonadal animals occurs earlier than in gonadally intact monkeys, which demonstrates that steroid feedback mechanisms also play a role in the later stages of pubertal maturation (Rapisarda et al. 1983). In the juvenile period there is a progressive decrease in sensitivity to the feedback effects of androgens and oestrogens. The high sensitivity at the start of the pubertal process explains why the initial menstrual/oestrous cycles are often anovulatory, or consist of short luteal phases or inadequate luteal function (Rapisarda et al. 1983, Foster 1994). Perhaps rather than considering the 'gonadostat' as a causal mechanism for puberty, it should be viewed as the necessary readjustment of gonadal steroid feedback loops which allows full ovarian and testicular activity to develop.

The capacity for this reactivation exists throughout the quiescent prepubertal period, as electrical and neurochemical stimulation of the hypothalamus have both been shown to release $\mathrm{LH}$, and by inference $\mathrm{GnRH}$. For example, treatment with the glutamate agonist $\mathrm{N}$-methylD-aspartate (NMDA) rapidly induces $\mathrm{LH}$ secretion in a wide range of prepubertal species including primates, sheep and rodents (Plant et al. 1989, Ebling \& Cronin 1998). Concurrent treatment with GnRH receptor antagonists blocks the effect of NMDA indicating a likely action on $\mathrm{GnRH}$ release rather than an action directly upon the pituitary gland (Lincoln \& Wu 1991). Moreover, in adult sheep, NMDA has been shown to increase
$\mathrm{GnRH}$ concentrations in the portal capillaries draining the median eminence (Viguie et al. 1995). Such evidence that the GnRH secretory system can be driven by exogenous activation supports the view that the endogenous stimulation of $\mathrm{GnRH}$ release is the rate-limiting step for puberty. The $\mathrm{GnRH}$ neuron may therefore be viewed as a very passive element in the pubertal process in that its secretion is entirely dependent upon inputs from higher centres.

\section{Neural inputs to GnRH neurons}

If from a neurobiological perspective the timing of puberty is a function of the activation of the $\mathrm{GnRH}$ secretory system by higher order mechanisms, then the precise identification of neural inputs to this system is paramount. Neuroendocrine studies in adult mammals employing pharmacological activation or blockade, in combination with neuroanatomical and electrophysiological techniques, have provided evidence that all the major monoamine and amino acid neurotransmitters can ultimately influence GnRH secretion (see Brann \& Mahesh 1997, Terasawa \& Fernandez 2001 for recent reviews). Likewise, a multitude of neuropeptides and systemically produced steroidal and peptide hormones can also ultimately modulate $\mathrm{GnRH}$ release. Such studies have not unequivocally demonstrated which pathways act directly upon $\mathrm{GnRH}$ neurons, or which inputs change during pubertal development, nor the relative importance of the plethora of different pathways. One problem in identifying inputs to $\mathrm{GnRH}$ neurons reflects the unusual development and organisation of the GnRH secretory system. The widespread and scattered distribution of individual cells has not been amenable to traditional electrophysiological techniques, but the creation of transgenic mice in which green fluorescent protein (GFP) is driven by a murine $\mathrm{GnRH}$ promotor has allowed recordings from identified $\mathrm{GnRH}$ neurons in hypothalamic slices (Spergel et al. 1999, Suter et al. 2000). Whole-cell current clamp recordings reveal that GFPtagged GnRH neurons fire spontaneous action potentials, although it does not appear that the firing patterns resemble the circhoral frequency of pulsatile $\mathrm{GnRH}$ release in vivo. Patch clamp studies reveal that all GFP-GnRH neurons are highly responsive to $\boldsymbol{\gamma}$-aminobutyric acid (GABA), and all show much lower amplitude responses to L-glutamate (Spergel et al. 1999). Consistent with these findings, single cell RT-PCR of forebrain cells identified as $\mathrm{GnRH}$ neurons on the basis of their morphology and subsequent amplification of GnRH mRNA has revealed the presence of a variety of GABA and glutamate receptor subunits within putative GnRH neurons (Herbison et al. 2001). This evidence for direct responses to GABA is consistent with studies indicating a role for GABA in both the initial development of the GnRH secretory system and in the differential regulation of $\mathrm{GnRH}$ secretion across puberty (Terasawa \& Fernandez 2001). Likewise, the evidence for 
direct glutamate responses via both AMPA and NMDA receptor complexes is consistent with the view that glutamate plays an important role in secretion of $\mathrm{GnRH}$ and in stabilisation of GnRH mRNA (Brann \& Mahesh, 1997, Hrabovszky et al. 2004). Spergel and colleagues (1999) recorded from GFP-GnRH neurons in tissue slices from mice ranging in age from 1 week to 6 months, but reported no differences in GABAergic or glutamatergic responses at different stages of reproductive development. This finding is consistent with the view that GnRH neurons are mature from very early in development and that increased secretion reflects changing signals to the $\mathrm{GnRH}$ secretory system rather than maturational changes within $\mathrm{GnRH}$ neurons themselves, for example changes in the expression of receptor subunits.

Immunoelectronmicroscopy studies suggest that the density of synaptic appositions on $\mathrm{GnRH}$-immunoreactivity (GnRH-ir) neurons is very much lower than that on surrounding neurons of unidentified phenotype (Lehman et al. 1988). A study comparing the density of synaptic inputs to GnRH neurons in seasonally anoestrus and ovulating sheep detected a twofold increase in synaptic appositions onto the cell soma and dendrites during the breeding season (Xiong et al. 1997). No such changes were detected in non-GnRH neurons in the surrounding preoptic area and the changes persisted in steroidclamped ovariectomised ewes, indicating that the synaptic changes were not secondary to changes in circulating sex steroid concentrations (Xiong et al. 1997). It is clear that the annual transitions in fertility in seasonally breeding mammals (recurrent annual puberty) share many characteristics with the pubertal process in non-seasonal mammals (Ebling \& Foster 1990), so a fascinating interpretation of the seasonal study is that puberty reflects the acquisition of stimulatory synaptic inputs to the GnRH secretory system. Such a 'structural plasticity' hypothesis is certainly consistent with the evidence presented above that $\mathrm{GnRH}$ neurons are passive elements in the pubertal process, and that puberty results from changes at a higher level. Rather few ultrastructural studies have been carried out to compare synaptic innervation of $\mathrm{GnRH}$-immunoreactive neurons in a developmental context, perhaps reflecting the inherent difficulty of the necessary techniques. In support of the 'structural plasticity' hypothesis, a study comparing gonadally intact prepubertal (29-day-old) and adult (3-month-old) male rats reported an increase in synaptic density on GnRH cell soma (Witkin \& Romero 1995), but studies in primates have been equivocal. One study in castrated juvenile and peripubertal male rhesus monkeys did not detect any developmental difference in the density of synapses onto GnRH dendrites (Perera \& Plant 1997), and reported a small decrease in synaptic density on GnRH perikarya in the mediobasal hypothalamus (Perera \& Plant 1997). A study in gonad-intact female rhesus monkeys did not detect any differences in synaptic densities between pubertal and adult monkeys (Witkin et al. 1991).
A fair comparison of these ultrastructural studies across species is not possible because of a myriad of differences relating to age, developmental status, sex, steroidal milieu, particular localisation of GnRH perikarya, and methods of analysis, but it would be premature to reject the 'structural plasticity' hypothesis on the basis of very limited studies in primates. Moreover, the focus of the above studies was on axosomatic and axodendritic synapses. Plasticity in glial ensheathment of GnRH terminals in the median eminence (Witkin \& Romero 1995), or even of synaptic input at this level (Durrant \& Plant 1999), might also alter GnRH release at puberty.

Immunocytochemical colocalisation of low amounts of receptor proteins within $\mathrm{GnRH}$ neurons has provided further evidence of neuropeptide pathways and hormonal signals that might modulate $\mathrm{GnRH}$ release. $\mathrm{GnRH}$ neurons in adult mammals express receptors for a number of peptides involved in hypothalamic regulation of energy balance, for example neuropeptide Y (NPY) (Li et al. 1999), and vasoactive intestinal peptide (VIP) (Smith et al. 2000), and receive appositions from metabolic peptidergic systems including CART (Cocaine and amphetamine-regulated transcript; Leslie et al. 2001) and orexin (Iqbal et al. 2001a). Fetal GnRH neurons have been shown to express growth factor receptors (e.g. brain-derived neurotrophic factor; BDNF) (Cronin et al. 2004), and recently expression of the GPR54 kisspeptin-receptor has been localised in $\mathrm{GnRH}$ neurons in the mouse (Messager et al. 2005). The GPR54 receptor is of particular interest since dysfunctional mutations of this receptor result in blocked pubertal maturation in both mouse and man (Seminara et al. 2003).

\section{The timing of puberty}

Perhaps the main difficulty in identifying specific inputs to the GnRH secretory system relates to its highly integrative function. The timing of puberty is clearly not a simple function of chronological age. At the individual level, there is a substantial heritability of the timing of puberty (Palmert \& Hirschhorn 2003 for review), but many internal and external factors impinge upon the genetic blueprint (Fig. 1). Both the onset of puberty and subsequent postpubertal reproductive function are affected by a huge number of sensory inputs relating to both the internal and external environment. Information about growth, body fat/composition, diet, stress, annual change in photoperiod, circadian time, gonadal steroids, energy expenditure in locomotor activity and olfactory cues all must ultimately reach the mammalian $\mathrm{GnRH}$ secretory system (Fig. 1), so it is no surprise that a large number of neurotransmitters and neuropeptides have been implicated in signalling to GnRH neurons. Moreover, although much of the current interest in environmental pollutants and endocrine disrupting chemicals (EDCs) has focused on direct actions on testicular development and function (Fisher 2004), one cannot rule out the possibility that they may 
also have actions within the brain upon $\mathrm{GnRH}$ synthesis and secretion (Fig. 1).

Many of the internal and external factors depicted in Fig. 1 have an effect on the timing of human puberty, so understanding how such information is transduced by the brain is currently of particular importance given certain lines of evidence in girls that the age of menarche is becoming earlier. One study in the USA (Herman-Giddens et al. 1997) collected data from over 17000 adolescent girls who attended family health practitioners for reasons other than those related to growth or reproductive development. This study revealed earlier onsets of breast development, pubic hair growth and menarche relative to norms defined two decades earlier. This advance in the age of attainment of pubertal markers correlates with an increasing prevalence of overweight body condition in adolescents; for example almost $25 \%$ of adolescents in the USA were overweight in 1994 as compared with 15\% in 1980 (Troiano \& Flegal 1998). Many studies have used cross-sectional data to substantiate the association between obesity and early sexual maturation in girls (Adair \& Gordon-Larsen 2001, Kaplowitz et al. 2001, Wang 2002). A recent longitudinal study provides further evidence for a link between body weight and onset of puberty, as those girls that had a higher body weight or body mass index earlier in childhood were more likely to initiate reproductive development at nine years of age than their peers (Davison et al. 2000). An outstanding review by Parent et al. (2003) provides a full analysis of the geographical prevalence of declining age of puberty, of the racial and environmental factors which might influence this, and of the question as to whether similar trends might exist in male populations, as some studies suggest a more complex relationship between early onset of fat deposition and pubertal maturation in boys (Wang 2002).

The correlation between body weight and onset of puberty has long been regarded as a causal relationship, encapsulated in the 'critical body weight' hypothesis (Frisch \& McArthur 1974). The causality has been established in many animal models. Across a wide range of species, restricting body weight gain by means of limited nutrition delays the timing of puberty (I'Anson et al. 1990 for review). The body weight hypothesis has been refined as it became clear that body composition and, more specifically, body fat were better predictors of puberty than body weight per se. Identifying a correlation between the earlier onset of weight gain/body fat, and the earlier onset of puberty raises the key question of the mechanistic link between energy metabolism and the $\mathrm{GnRH}$ secretory system. The most contemporary view is that it is metabolic fuel (caloric) availability that is the key element determining reproductive function (Schneider et al. 2000); thus fat deposition is a correlate of the positive energy balance rather than the causal factor. This view stems from the rapidity with which increased energetic challenges (starvation, enforced activity) can suppress ovulatory cycles and reproductive behaviour in female mammals if insufficient fat reserves are available to meet these demands (Bronson 2000, Schneider \& Wade 2000).

The discovery of leptin in 1994 (Zhang et al. 1994) further complicates the metabolic fuels versus body fat debate. This adipocyte-derived cytokine is clearly an important element in energy homeostasis in that it negatively feeds back via receptors in the hypothalamus to reduce caloric intake and to increase caloric expenditure (Friedman \& Halaas 1998). A role for leptin in the timing of puberty was hinted at by the observation that genetically mutant mice lacking leptin production $(o b / o b)$ or leptin receptors $(d b / d b)$ did not undergo normal puberty despite being grossly obese (Batt et al. 1982). Replacement administration of leptin to $o b / o b$ mice induces reproductive development (Foster \& Nagatani 1999 for review), and likewise leptin therapy has been shown to increase gonadotrophin secretion in an obese child congenitally lacking leptin (Farooqi et al. 1999). The observations in $o b / o b$ mice, coupled with studies in which leptin treatment of prepubertal mice slightly advance the age of vaginal opening (Chehab et al. 1997), led to the concept that leptin was a trigger for puberty, signalling the presence of sufficient fat reserves to begin the energetically costly process of reproduction. However, subsequent studies in rats have failed to repeat the observation that leptin treatment can advance puberty in wild-type individuals, although it can overcome the delay in puberty induced by food restriction (Cheung et al. 1997). Measurements of circulating leptin in rodents and primates have failed to identify a specific rise at the time when increased gonadotrophin secretion is occurring (Ahima et al. 1998, Urbanski \& Pau 1998, Plant \& BarkerGibb 2004). The situation in children is more complex. In girls there are gradual age- and body weight-related increases in circulating leptin concentrations (Clayton et al. 1997). In boys, leptin levels are considerably lower than in girls, but also rise until the early stages of puberty after which they decline (Demerath et al. 1999). This sex difference may represent stimulatory effects of oestrogens on leptin production and inhibitory actions of testosterone (Demerath et al. 1999). Collectively, these observations favour the view that leptin provides a permissive 'gate' for puberty rather than a causal 'trigger'. In human development, we must look for factors in addition to leptin to explain the timing of puberty, although in wild mammals experiencing highly variable food supply, sub-threshold circulating leptin concentrations might be an important signal to delay puberty in favour of processes necessary for immediate survival including increased appetite, reduced metabolic rate and thermogenesis.

It seems unlikely that leptin acts directly upon $\mathrm{GnRH}$ neurons since $\mathrm{GnRH}$ perikarya are mainly located rostral to the hypothalamic areas expressing leptin receptors (Mercer et al. 1996). However, a number of peptidergic cell phenotypes in more caudal areas of the hypothalamus do colocalise leptin receptors, for example NPY/agoutirelated peptide (AgRP) and pro-opiomelanocortin 
(POMC)/CART neurons in the arcuate nucleus, and melanin concentrating hormone $(\mathrm{MCH})$ and orexin neurons in the lateral hypothalamus (Hakansson et al. 1988, Iqbal et al. 2001b). Moreover, leptin clearly regulates the activity of multiple hypothalamic peptidergic systems implicated in the control of energy metabolism (for example $\mathrm{MCH}, \mathrm{NPY}, \mathrm{CART}$, orexin), many of which have been shown to extend rostral projections to areas implicated in the control of GnRH secretion (Parent et al. 2000). Given the profound hypogonadotrophism seen when GPR54 receptor signalling is dysfunctional (Seminara et al. 2003), an intriguing possibility is that direct metabolic regulation of the $\mathrm{GnRH}$ secretory system is via GPR54 receptors known to be expressed in GnRH neurons (Messager et al. 2005). The finding that hypothalamic KiSS-1 mRNA abundance increases at the time of increased pubertal GnRH secretion in agonadal male and intact female rhesus monkeys is consistent with the hypothesis that the kisspeptin-GPR54 system contributes to the timing of puberty (Shahab et al. 2005). A demonstration that local production and release of ligands (kisspeptins) in the vicinity of $\mathrm{GnRH}$ neurons changes through pubertal development or in relation to energy balance is eagerly awaited.

\section{Summary and future directions}

Major advances have occurred in the last decade or so in understanding the timing of puberty. These include the discovery that $\mathrm{GnRH}-\mathrm{I}$ neurons develop in the olfactory placode and migrate into the forebrain, the recognition that puberty is a reactivation of $\mathrm{GnRH}$ secretion, the identification of peripheral metabolic signals which may permit puberty to occur, and the identification of GPR54 as a key signalling pathway to $\mathrm{GnRH}$ neurons. Progress has also been made in identifying the neural mechanisms by which external environmental cues time puberty. These include the unravelling of the molecular basis of the circadian clock that underlies photoperiodic control of puberty in seasonal species (Lincoln et al. 2003 for review) and the identification of the structure of a class of pheromones in urine which regulate puberty via effects on vomeronasal neurons (Leinders-Zufall et al. 2000). The discovery of other populations of $\mathrm{GnRH}$ neurons in mammals expressing the GnRH-Il gene (Latimer et al. 2000) is intriguing, but the functional significance, if any, is currently unclear. These advances generate further questions: what regulates the migratory pathways of GnRH neurons, and what controls axon outgrowth and targeting to the median eminence? What is the mechanism that causes $\mathrm{GnRH}$ secretion to decline between the neonatal and prepubertal phase of development in mammals with relatively long life spans? How do metabolic fuels and metabolic hormones such as leptin and other sensory inputs finally communicate to the $\mathrm{GnRH}$ neuron? How do GnRH neurons communicate with each other such that co-ordinated pulsatile release of $\mathrm{GnRH}$ occurs? What is the function of GnRH-II? Some of these issues may be better addressed using the transgenic technologies which allow the identification and thus the recording, sampling and observation of GnRH neurons in living tissue, but in order to understand how internal and external cues time puberty it will also be important to study a variety of other mammalian models in which the relative importance of such inputs differs.

\section{Acknowledgement}

Studies in the author's laboratory are funded by the BBSRC (project grants 42/S17106 and BBS/B/10765) and by AstraZeneca. Many thanks to Doug Foster and Gerald Lincoln who stimulated my early interest in this area. I declare that there is no conflict of interest that would prejudice the impartiality of this scientific work.

\section{References}

Adair LS \& Gordon-Larsen P 2001 Maturational timing and overweight prevalence in US adolescent girls. American Journal of Public Health 91 642-644.

Ahima RS, Prabakaran D \& Flier JS 1998 Postnatal leptin surge and regulation of circadian rhythms of leptin by feeding: implications for energy homeostasis and neuroendocrine function. Journal of Clinical Investigation 101 1020-1027.

Batt RAL, Everard DM, Gillies G, Wilkinson M, Wilson CA \& Yeo TA 1982 Investigation into the hypogonadism of the obese mouse (genotype ob/ob). Journal of Reproduction and Fertility 64 363-371.

Brann DW \& Mahesh VB 1997 Excitatory amino acids: evidence for a role in the control of reproduction and anterior pituitary hormone secretion. Endocrine Reviews 18 678-700.

Bronson FH 2000 Puberty and energy reserves: a walk on the wild side. In Reproduction in Context, pp 15-33. Eds K Wallen \& JE Schneider. Cambridge, MA: MIT Press.

Brooks AN, McNeilly AS \& Thomas GB 1995 Role of GnRH in the ontogeny and regulation of the fetal hypothalamo-pituitary-gonadal axis in sheep. In Reproduction in Domestic Ruminants III, Journal of Reproduction and Fertility Supplement, 49, pp 163-175. Eds RJ Scaramuzzi, CD Nancarrow, C Doberska. Cambridge: Journals of Reproduction and Fertility Ltd.

Cattanach BM, Iddon CA, Charlton HM, Chiappa SA \& Fink G 1977 Gonadotropin releasing hormone deficiency in a mutant mouse with hypogonadism. Nature $269338-340$.

Charlton HM 2004 Neural transplantation in hypogonadal (hpg) mice - physiology and neurobiology. Reproduction 127 3-12.

Chehab FF, Mounzih K, Lu R \& Lim ME 1997 Early onset of reproductive function in normal female mice treated with leptin. Science 275 88-90.

Cheung CC, Thornton JE, Kuijper JL, Weigle DS, Clifton DK \& Steiner RA 1997 Leptin is a metabolic gate for the onset of puberty in the female rat. Endocrinology 138 855-857.

Clayton PE, Gill MS, Hall CM, Tillmann V, Whatmore AJ \& Price DA 1997 Serum leptin through childhood and adolescence. Clinical Endocrinology 46 727-733.

Cronin AS, Horan TL, Spergel DJ, Brooks AN, Hastings MH \& Ebling FJP 2004 Neurotrophic effects of BDNF on embryonic gonadotropin-releasing hormone $(\mathrm{GnRH})$ neurons. European Journal of Neuroscience 19 338-344.

Davison KK, Susman EJ \& Birch LL 2000 Percent body fat at age 5 predicts earlier pubertal development among girls at age 9. Pediatrics 111 815-823. 
Demerath EW, Towne B, Wisemandle W, Blanger J, Chumlea WC \& Siervogel RM 1999 Serum leptin concentration, body composition, and gonadal hormones during puberty. International Journal of Obesity 23 678-685.

Dudas B \& Merchenthaler IJ 2003 Topography and associations of leu-enkephalin and luteinizing hormone-releasing hormone neuronal systems in the human diencephalon. Journal of Clinical Endocrinology and Metabolism 88 1842-1848.

Durrant AR \& Plant TM 1999 A study of the gonadotropin releasing hormone neuronal network in the median eminence of the rhesus monkey (Macaca mulatta) using a post-embedding immunolabelling procedure. Journal of Neuroendocrinology $\mathbf{1 1}$ 813-821.

Dutlow CM, Rachman J, Jacobs TW \& Millar RP 1992 Prepubertal increases in gonadotropin-releasing hormone mRNA, gonadotropin-releasing hormone precursor, and subsequent maturation of precursor processing in male rats. Journal of Clinical Investigation 90 2496-2501.

Ebling FJP 1994 Photoperiodic differences during development in the dwarf hamsters Phodopus sungorus and Phodopus campbelli. General and Comparative Endocrinology 95 475-482.

Ebling FJP \& Foster DL 1990 Seasonal breeding - a model for puberty? In Control of the Onset of Puberty III, pp 253-264. Eds HA Delamarre-van de Waal, TM Plant, GP van Rees, J Shoemaker. Amsterdam: Excerpta Medica.

Ebling FJP \& Cronin AS 1998 Manipulations of glutamatergic (N-methyl-D-aspartate receptor) neurotransmission alter the rate of photoperiodically regulated sexual maturation in the male Siberian hamster. Biology of Reproduction 58 1-7.

Ebling FJP \& Cronin AS 2000 The neurobiology of reproductive development. NeuroReport 11 R23-R33.

Farooqi IS, Jebb SA, Langmack G, Lawrence E, Cheetham $\mathbf{C H}$, Prentice AM, Hughes IA, McCamish MA \& O'Rahilly S 1999 Effects of recombinant leptin therapy in a child with congenital leptin deficiency. New England Journal of Medicine 341 879-884.

Fernald RD \& White RB 1999 Gonadotropin-releasing hormone genes: phylogeny, structure and functions. Frontiers in Neuroendocrinology $20224-240$.

Fisher JS 2004 Environmental anti-androgens and male reproductive health: focus on phthalates and testicular dysgenesis syndrome. Reproduction 127 305-315.

Ford H \& Ebling FJP 2000 Glutamatergic regulation of GnRH mRNA levels during development in the mouse. Journal of Neuroendocrinology 12 1027-1033.

Foster DL 1994 Puberty in sheep. In The Physiology of Reproduction, pp 411-451. Eds E Knobil \& JD Neill. New York: Raven Press Ltd.

Foster DL \& Nagatani S 1999 Physiological perspectives on leptin as a regulator of reproduction: role in timing puberty. Biology of Reproduction 60 205-215.

Fraser MO, Pohl CR \& Plant TM 1989 The hypogonadotropic state of the prepubertal male rhesus monkey (Macaca mulatta) is not associated with a decrease in hypothalamic gonadotropin-releasing hormone content. Biology of Reproduction 40 972-980.

Friedman JM \& Halaas JL 1998 Leptin and the regulation of body weight in mammals. Nature $395763-770$.

Frisch RE \& McArthur JW 1974 Menstrual cycles: fatness as a determinant of minimum weight for height necessary for their maintenance or onset. Science 185 949-951.

Gibson MJ, Kreiger DT, Charlton HM, Zimmerman EA, Silverman AJ \& Perlow MJ 1984 Mating and pregnancy can occur in genetically hypogonadal mice with preoptic area brain grafts. Science 225 949-951.

Gore AC \& Roberts JL 1997 Regulation of gonadotropin-releasing hormone gene expression in vivo and in vitro. Frontiers in Neuroendocrinology 18 209-245.

Gore AC, Wu TJ, Rosenberg JJ \& Roberts JL 1996 Gonadotropinreleasing hormone and NMDA receptor gene expression and colocalisation change during puberty in female rats. Journal of Neuroscience 16 5281-5289.
Gore AC, Roberts JL \& Gibson MJ 1999 Mechanisms for the regulation of gonadotropin-releasing hormone gene expression in the developing mouse. Endocrinology 140 2280-2287.

Hakansson ML, Brown H, Ghilardi N, Skoda RC \& Meister B 1998 Leptin receptor immunoreactivity in chemically defined target neurons of the hypothalamus. Journal of Neuroscience $\mathbf{1 8}$ 559-572.

Herbison AE, Pape JR, Simonian SX, Skynner MJ \& Sim JA 2001 Molecular and cellular properties of $\mathrm{GnRH}$ neurons revealed through transgenics in the mouse. Molecular and Cellular Endocrinology 185 185-194.

Herman-Giddens ME, Slora EJ, Wasserman RC, Bourdony CJ, Bhapkar MV, Koch GG \& Hasemeier CM 1997 Secondary sexual characteristics and menses in young girls seen in office practise: a study from the pediatric research in office settings network. Pediatrics 99 505-512.

Hrabovszky E, Turi GF, Kallo I \& Liposits Z 2004 Expression of vesicular glutamate transporter-2 in gonadotropin-releasing hormone neurons of the adult male rat. Endocrinology 145 4018-4021.

I'Anson H, Foster DL, Foxcroft GR \& Booth PJ 1990 Nutrition and reproduction. Oxford Reviews of Reproductive Biology 13 239-311.

Iqbal J, Pompolo S, Sakurai T \& Clarke IJ 2001a Evidence that orexin-containing neurones provide direct input to gonadotropinreleasing hormone neurones in the ovine hypothalamus. Journal of Neuroendocrinology 13 1033-1041.

Iqbal J, Pompolo S, Murakami T, Grouzmann E, Sakurai T, Meister B \& Clarke IJ 2001 b Immunohistochemical characterization of localization of long-form leptin receptor (OB-Rb) in neurochemically defined cells in the ovine hypothalamus. Brain Research 920 $55-64$.

Kaplowitz PB, Slora EJ, Wasserman RC, Pedlow SE \& Herman-Giddens ME 2001 Earlier onset of puberty in girls: relation to increased body mass index and race. Pediatrics 108 347-353.

Latimer VS, Rodrigues SM, Garyfallou VT, Kohama SG, White RB, Fernald RD \& Urbanski HF 2000 Two molecular forms of gonadotropin-releasing hormone (GnRH-I and $\mathrm{GnRH}-\mathrm{II})$ are expressed by two separate populations of cells in the rhesus macaque hypothalamus. Molecular Brain Research 75 287-292.

Lehman MN, Karsch FJ, Robinson JE \& Silverman AJ 1988 Ultrastructure and synaptic organization of luteinizing hormone-releasing hormone $(\mathrm{LHRH})$ neurons in the anestrous ewe. Journal of Comparative Neurology 273 447-458.

Leinders-Zufall T, Lane AP, Puche AC, Ma W, Novotny MV, Shipley MT \& Zufall F 2000 Ultrasensitive pheromone detection by mammalian vomeronasal neurons. Nature 405 792-796.

Leslie RA, Sanders SJK, Anderson S, Schuhler S, Horan TL \& Ebling FJP 2001 Appositions between CART- and GnRH-immunoreactive neurons in the hypothalamus. Neuroscience Letters 314 $111-114$

Li C, Chen PL \& Smith MS 1999 Morphological evidence for direct interaction between arcuate nucleus neuropeptide $\mathrm{Y}$ (NPY) neurons and gonadotropin-releasing hormone neurons and the possible involvement of NPYY1 receptors. Endocrinology $1405382-5390$.

Lincoln GA \& Wu FCW 1991 Luteinizing responses to N-methylD,L-aspartate during a photoperiodically-induced reproductive cycle in the ram. Journal of Neuroendocrinology 3 309-317.

Lincoln GA, Andersson H \& Loudon ASI 2003 Clock genes in calendar cells as the basis of annual timekeeping in mammals - a unifying hypothesis. Journal of Endocrinology 179 1-13.

MacColl G, Bouloux PMG \& Quinton R 2002 Kallmann syndrome: adhesion, afferents and anosmia. Neuron 34 675-678.

Mann DR \& Fraser HM 1996 The neonatal period: a critical interval in male primate development. Journal of Endocrinology 149 191-197.

Mason AJ, Pitts SL, Nikolics K, Szonyi E, Wilcox JN, Seeburg PH \& Stewart TA 1986 The hypogonadal mouse: reproductive functions restored by gene therapy. Science 234 1372-1378.

Mercer JG, Hoggard N, Williams LM, Lawrence B, Hannah LT \& Trayhurn P 1996 Localization of leptin receptor mRNA and the long 
form splice variant $(\mathrm{Ob}-\mathrm{Rb})$ in mouse hypothalamus and adjacent brain regions by in situ hybridization. FEBS Letters 387 113-116.

Mesiano S, Hart CS, Heyer BW, Kaplan SL \& Grumbach MM 1991 Hormone ontogeny in the ovine fetus XXVI. A sex difference in the effects of castration on the hypothalamo-pituitary gonadotropin unit in the ovine fetus. Endocrinology 129 3073-3079.

Messager S, Chatzidaki EE, Ma D, Hendrick AG, Zahn D, Dixon J, Thresher RR, Malinge I, Lomet D, Carlton MBL, Colledge WH, Caraty A \& Aparicio SAJR 2005 Kisspeptin directly stimulates gonadotropin-releasing hormone release via the G protein-coupled receptor 54. PNAS 102 1761-1766.

Munoz A \& Dieguez E 1997 A plea for proper recognition: the syndrome of Maestre de San Juan-Kallman. American Journal of Neuroradiology 18 1395-1396.

Palmert MR \& Hirschhorn JN 2003 Genetic approaches to stature, pubertal timing, and other complex traits. Molecular Genetics and Metabolism 80 1-10.

Parent AS, Lebrethon MC, Gerard A, Vandersmissen E \& Bourguignon JP 2000 Leptin effects on pulsatile gonadotropin releasing hormone secretion from the adult rat hypothalamus and interaction with cocaine and amphetamine regulated transcript peptide and neuropeptide Y. Regulatory Peptides 92 17-24.

Parent AS, Teilmann GJ, Juul A, Skakkebaek NE, Toppari J \& Bourguignon JP 2003 The timing of normal puberty and the age limits of sexual precocity: variations around the world, secular trends, and changes after migration. Endocrine Reviews 24 668-693.

Perera AD \& Plant TM 1997 Ultrastructural studies of neuronal correlates of the pubertal reaugmentation of hypothalamic gonadotropin-releasing hormone $(\mathrm{GnRH})$ release in the rhesus monkey (Macaca mulatta). Journal of Comparative Neurology 385 71-82.

Plant TM 1985 A study of the role of the postnatal testes in determining the ontogeny of gonadotropin secretion in the male rhesus monkey (Macaca mulatta). Endocrinology $\mathbf{1 1 6}$ 1341-1350.

Plant TM 2001 Neurobiological bases underlying the control of the onset of puberty in the rhesus monkey: a representative higher primate. Frontiers in Neuroendocrinology 22 107-139.

Plant TM \& Barker-Gibb ML 2004 Neurobiological mechanisms of puberty in higher primates. Human Reproduction Update $\mathbf{1 0}$ $67-77$.

Plant TM, Gay VL, Marshall GR \& Arslan M 1989 Puberty in monkeys is triggered by chemical stimulation of the hypothalamus. PNAS 86 2506-2510.

Pohl CR, deRidder CM \& Plant TM 1995 Gonadal and nongonadal mechanisms contribute to the prepubertal hiatus in gonadotropin secretion in the female rhesus monkey (Macaca mulatta). Journal of Clinical Endocrinology and Metabolism 80 2094-2101.

Quinton R, Duke VM, de Zoysa PA \& Bouloux PMG 1996 The neurobiology of Kallmann's syndrome. Human Reproduction 11 $121-127$.

Rapisarda JJ, Bergman KS, Steiner RA \& Foster DL 1983 Response to estradiol inhibition of tonic luteinizing hormone secretion decreases during the final stage of puberty in the rhesus monkey. Endocrinology $1121172-1178$.

Schneider JE \& Wade GN 2000 Reproductive inhibition in service of energy balance. In Reproduction in Context, pp 34-82. Eds K Wallen \& JE Schneider. Boston: MIT Press.

Schneider JE, Zhou D \& Blum RM 2000 Leptin and metabolic control of reproduction. Hormones and Behavior 37 306-326.

Seminara SB, Messager S, Chatzidaki EE, Thresher RR, Acierno JS, Shagoury JK, Bo-Abbas Y, Kuohung W, Schwinof KM, Hendrick AG, Zahn D, Dixon J, Kaiser UB, Slaugenhaupt SA, Gusella JF, O'Rahilly S, Carlton MBL, Crowley WF, Aparicio SAJR \& Colledge WH 2003 The GPR54 gene as a regulator of puberty. New England Journal of Medicine 349 1614-1627.

Shahab M, Mastronardi C, Seminara SB, Crowley WF, Ojeda SR \& Plant TM 2005 Increased hypothalamic GPR54 signaling: a potential mechanism for initiation of puberty in primates. PNAS 102 2129-2134.
Smith MJ, Jennes L \& Wise PM 2000 Localization of the VIP2 receptor protein on $\mathrm{GnRH}$ neurons in the female rat. Endocrinology 141 4317-4320.

Song T, Nikolics K, Seeburg PH \& Goldsmith PC 1987 GnRH-prohormone-containing neurons in the primate brain: immunostaining for the GnRH-associated peptide. Peptides 8 335-346.

Spergel DJ, Kruth U, Hanley DF, Sprengel R \& Seeburg PH 1999 GABA- and glutamate-activated channels in green fluorescent protein-tagged gonadotropin-releasing hormone neurons in transgenic mice. Journal of Neuroscience 19 2037-2050.

Suter KJ, Wuarin JP, Smith BN, Dudek FE \& Moenter SM 2000 Whole-cell recordings from preoptic/hypothalamic slices reveal burst firing in gonadotropin-releasing hormone neurons identified with green fluorescent protein in transgenic mice. Endocrinology $1413731-3736$.

Terasawa E \& Fernandez DL 2001 Neurobiological mechanisms of the onset of puberty in primates. Endocrine Reviews 22 111-151.

Tobet SA, Bless EP \& Schwarting GA 2001 Developmental aspect of the gonadotropin-releasing hormone system. Molecular and Cellular Endocrinology 185 173-184.

Troiano RP \& Flegal KM 1998 Overweight children and adolescents: description, epidemiology, and demographics. Pediatrics 101 497-504.

Urbanski HF \& Pau KYF 1998 A biphasic pattern of circulating leptin in the male rhesus macaque (Macaca mulatta). Endocrinology 139 2284-2286.

Vician L, Adam LA, Clifton DK \& Steiner RA 1991 Pubertal changes in pro-opiomelanocortin and gonadotropin-releasing hormone gene expression in the brain of the male monkey. Molecular and Cellular Neuroscience 2 31-38.

Viguie C, Caraty A, Locatelli A \& Malpaux B 1995 Regulation of luteinizing hormone-releasing hormone (LHRH) secretion by melatonin in the ewe II: changes in N-methyl-D,L- aspartic acidinduced LHRH release during the stimulation of luteinising hormone secretion by melatonin. Biology of Reproduction $\mathbf{5 2}$ $1156-1161$.

Wang Y 2002 Is obesity associated with early sexual maturation? A comparison of the association in American boys versus girls. Pediatrics 110 903-910.

Wiemann JN, Clifton DK \& Steiner RA 1989 Pubertal changes in gonadotropin-releasing hormone and proopiomelanocortin gene expression in the brain of the male rat. Endocrinology 124 1760-1767.

Wildt L, Marshall G \& Knobil E 1980 Experimental induction of puberty in the infantile female rhesus monkey. Science $\mathbf{2 0 7}$ $1373-1375$

Witkin JW 1990 Access of luteinizing hormone-releasing hormone to the vasculature in the rat. Neuroscience 37 501-506.

Witkin JW \& Romero MT 1995 Comparison of ultrastructural characteristics of gonadotropin-releasing-hormone neurons in prepubertal and adult male-rats. Neuroscience 64 1145-1151.

Witkin JW, Ferin M, Popilskis SJ \& Silverman AJ 1991 Effects of gonadal steroids on the ultrastructure of $\mathrm{GnRH}$ neurons in the rhesus monkey - synaptic input and glial apposition. Endocrinology 129 1083-1092.

Xiong JJ, Karsch FJ \& Lehman MN 1997 Evidence for seasonal plasticity in the gonadotrophin-releasing hormone $(\mathrm{GnRH})$ system of the ewe: changes in synaptic inputs onto $\mathrm{GnRH}$ neurons. Endocrinology 138 1240-1250.

Zhang Y, Proenca R, Maffei M, Barone M, Leopold L \& Friedman JM 1994 Positional cloning of the mouse obese gene and its human homologue. Nature 372 425-432.

Received 11 February 2005

First decision 7 March 2005

Revised manuscript received 17 March 2005

Accepted 23 March 2005 